\title{
Lungs Partial Response GvHD
}

National Cancer Institute

\section{Source}

National Cancer Institute. Lungs Partial Response GVHD. NCI Thesaurus. Code C126721.

Either an increase by $10 \%$ predicted absolute value of $\% \mathrm{FEV} 1$ or an NIH lung symptom score that has decreased by 1 or more points. 